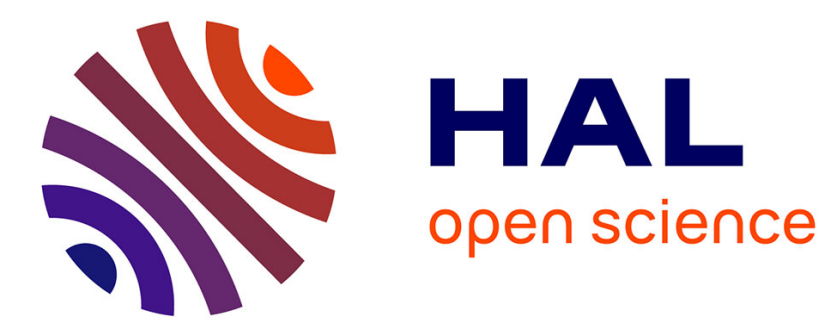

\title{
A NEW STRUCTURE OF A SWITCHING FLUX SYNCHRONOUS POLYPHASED MACHINE WITH HYBRID EXCITATION
}

Emmanuel Hoang, Michel Lécrivain, Mohamed Gabsi

\section{> To cite this version:}

Emmanuel Hoang, Michel Lécrivain, Mohamed Gabsi. A NEW STRUCTURE OF A SWITCHING FLUX SYNCHRONOUS POLYPHASED MACHINE WITH HYBRID EXCITATION. EPE 2007, Sep 2007, Aalborg, Denmark. hal-00532995

\section{HAL Id: hal-00532995 https://hal.science/hal-00532995}

Submitted on 4 Nov 2010

HAL is a multi-disciplinary open access archive for the deposit and dissemination of scientific research documents, whether they are published or not. The documents may come from teaching and research institutions in France or abroad, or from public or private research centers.
L'archive ouverte pluridisciplinaire HAL, est destinée au dépôt et à la diffusion de documents scientifiques de niveau recherche, publiés ou non, émanant des établissements d'enseignement et de recherche français ou étrangers, des laboratoires publics ou privés. 


\title{
A NEW STRUCTURE OF A SWITCHING FLUX SYNCHRONOUS POLYPHASED MACHINE WITH HYBRID EXCITATION
}

\author{
Emmanuel HoAnG, Michel LeCRIVAIN, Mohamed GABSI \\ SATIE - Ecole Normale Supérieure de Cachan, UMR CNRS 8029, Cachan FRANCE \\ Phone number: (33) 147402111 \\ Fax : (33) 147402199 \\ E-mail: hoang@satie.ens-cachan.fr
}

\begin{abstract}
The aim of this paper is to present the structure of a new flux switching synchronous machine with hybrid excitation. This machine uses the flux switching principle where all the active parts are located on the stator. The rotor is only a salient passive rotor and can be robust and made with a low cost technology. This new machine can be supplied with electricity by means of a traditional three phase voltage converter or can be associated with a diode rectifier. The hybrid excitation is an association of permanent magnets and a wound exciter.
\end{abstract}

Keywords: Synchronous machine, permanent magnet, flux switching, flux weakening, hybrid excitation, magnetic losses.

\section{Machine presentation}

As shown in Fig. 1, an elementary magnetic cell serves to explain (see part 2) the operating principle of this new structure of the flux switching synchronous machine with a hybrid excitation [1]. This particular structure uses the principle of both flux switching and flux concentration [2-4]. From the elementary cell, we developed a prototype (see Fig. 2).

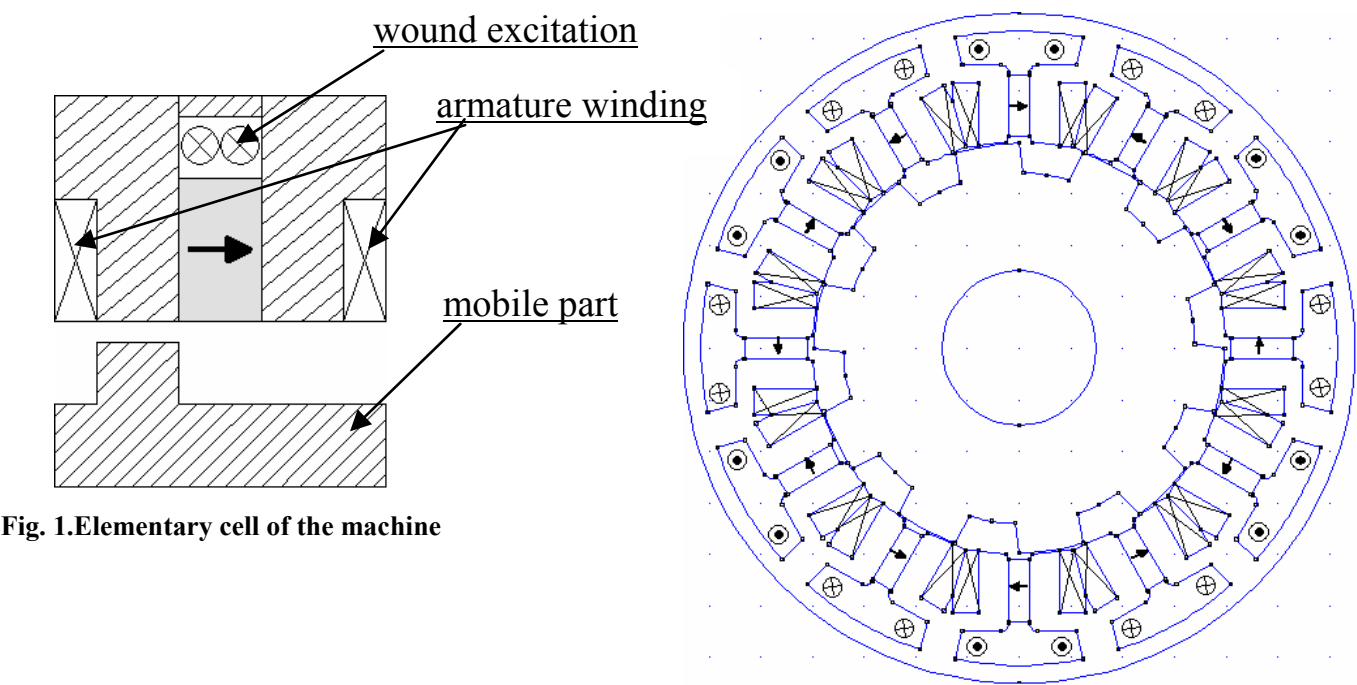

Fig. 2. Cross section of a three phases prototype

This machine is composed of a stator that includes armature coils, permanent magnets and a wound inductor. The salient rotor is simply made of stacked soft iron sheets. The prototype is a three phase machine containing twelve magnets, with each phase composed of four magnets and four concentric coils. The rotor contains $\mathrm{N}_{\mathrm{r}}$ teeth (with $\mathrm{N}_{\mathrm{r}}=10$ ), and the relation between the mechanical rotation frequency $F$ and the electrical frequency $f$ can be expressed as: $f=N_{r} F$. 


\section{Principle of functioning}

According to the position of the mobile part, the magnetic flux linkage in the armature winding can be counted as either positive or negative, and is then alternative. In this new structure, with the excitation current it is possible to modulate the excitation of the permanent magnets.

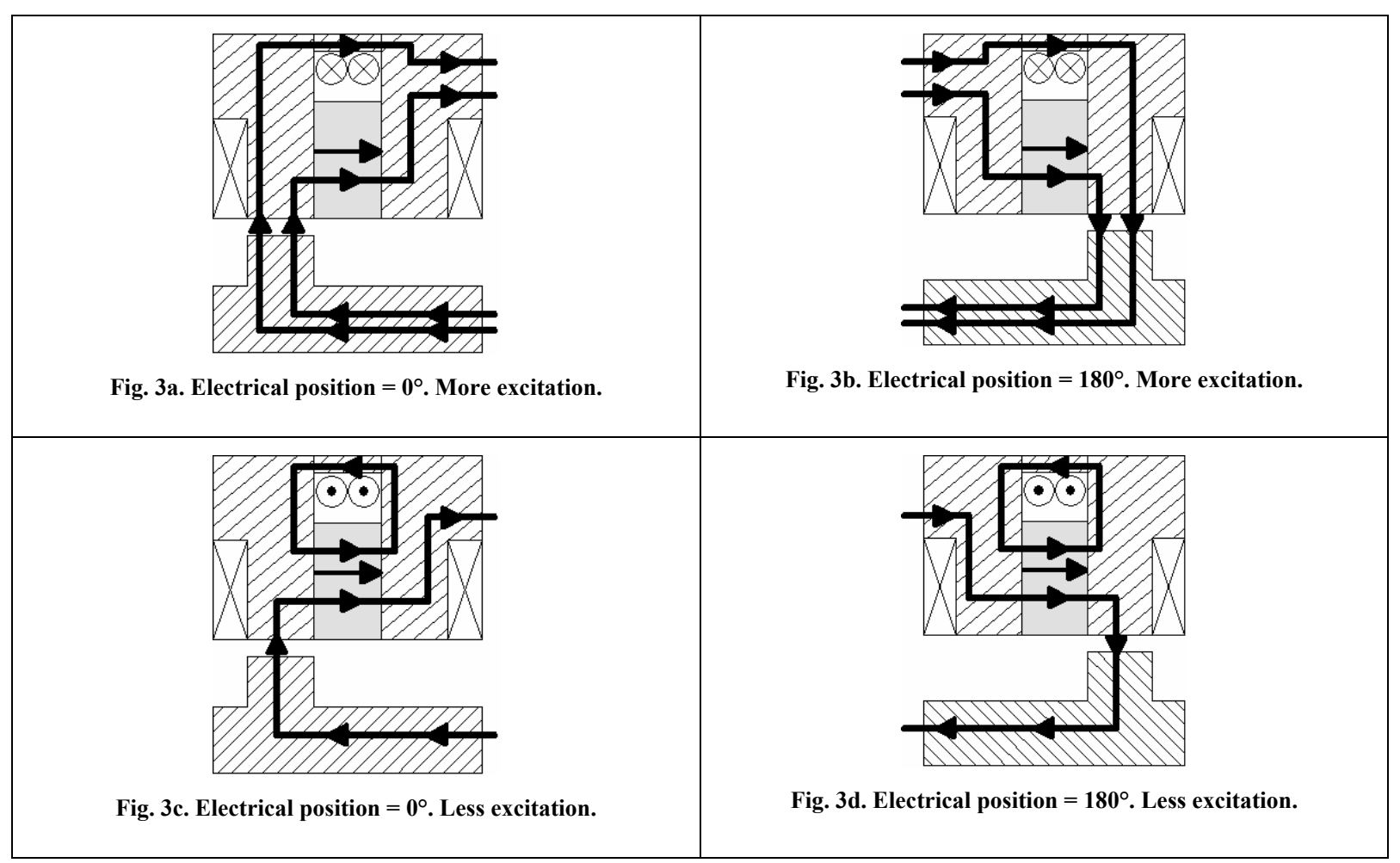

\section{Structure}

We define the following parameters :

$\mathrm{q}:$ number of phases

$\mathrm{N}_{\mathrm{c}}$ : number of cells per phase

$\theta_{\mathrm{S}}:$ angular width of the cell to the stator

$\theta \mathrm{r}$ : angular width of the cell to the rotor

$\mathrm{N}_{\mathrm{S}}$ : number of teeth to the stator

$\mathrm{Nr}$ : number of teeth to the rotor

$\mathrm{w}_{\mathrm{s}}$ : angular width of a stator tooth

$\mathrm{w}_{\mathrm{r}}$ : angular width of a rotor tooth

The relations making it possible to define a polyphase structure are as follows :

$\mathrm{N}_{\mathrm{r}} \theta_{\mathrm{r}}=2 \pi$ and $\mathrm{N}_{\mathrm{s}} \theta_{\mathrm{s}}=2 \pi$

$\theta_{\mathrm{s}}=\frac{2 \pi}{\mathrm{qN}_{\mathrm{c}}} ; \theta_{\mathrm{s}}=2 \pi_{\text {elec }}\left(1 \pm \frac{\mathrm{k}}{2 \mathrm{q}}\right)$ and $\theta_{\mathrm{r}}=2 \pi_{\text {elec }}$ with $\mathrm{k}$, natural entirety

Then, $\theta_{\mathrm{r}}=\frac{\theta_{\mathrm{s}}}{\left(1 \pm \frac{\mathrm{k}}{2 \mathrm{q}}\right)}$

We also have, for reasons of symmetries : $\mathrm{w}_{\mathrm{s}}=\frac{\theta_{\mathrm{s}}}{4}$

The angular width of the rotor teeth is defined by : $\mathrm{w}_{\mathrm{r}}=\beta_{\mathrm{r}} \theta_{\mathrm{r}}$ with $\left.\beta_{\mathrm{r}} \in\right] 0 ; 1[$

In order to balance the radial efforts and to minimize the harmonic components of flows, the numbers of teeth to the stator $\left(\mathrm{N}_{\mathrm{s}}\right)$ and the rotor $\left(\mathrm{N}_{\mathrm{r}}\right)$ must even beings. 
For a three-phase machine $(\mathrm{q}=3)$ and with $\mathrm{N}_{\mathrm{c}}=4$, we obtain: $\mathrm{N}_{\mathrm{s}}=12$ and $\mathrm{N}_{\mathrm{r}}=10$.

For a diphasic machine $(\mathrm{q}=2)$ and with $\mathrm{N}_{\mathrm{c}}=4$, we obtain: $\mathrm{N}_{\mathrm{s}}=8$ and $\mathrm{N}_{\mathrm{r}}=6$.

We built a three-phase machine. On figures 4 and 5 we can see the stator. On figure 4, there is only the carcass out of aluminium with ferromagnetic sheets. On figure 5, we can see windings of the three phases and excitation circuit.

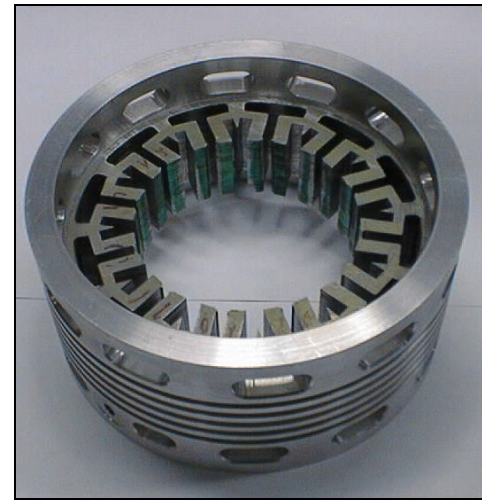

Fig. 4. Stator iron core

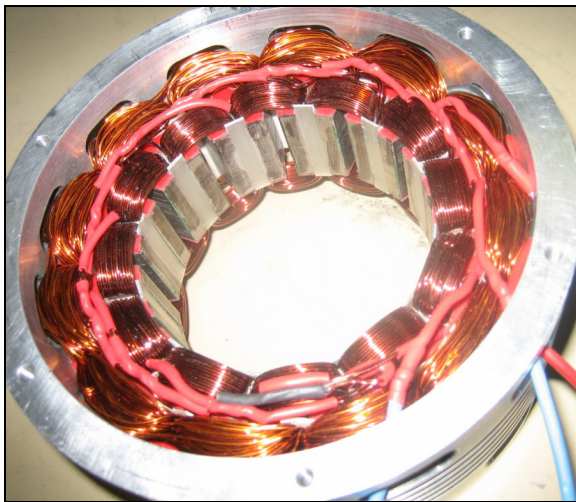

Fig. 5. Stator iron core and winding

Also, all the active parts are arranged on the static part (stator) which is beneficial to evacuating the copper and iron losses.

\section{EMF (no-load voltage)}

\subsection{Modulation of the amplitude}

In Fig. 6, we show that the no-load voltage is almost sinusoidal and that it is possible to modulate their amplitude $\left(\mathrm{d}_{\mathrm{exc}}\right.$ is the current density of the wound excitation in $\left.\mathrm{A} / \mathrm{mm}^{2}\right)$.

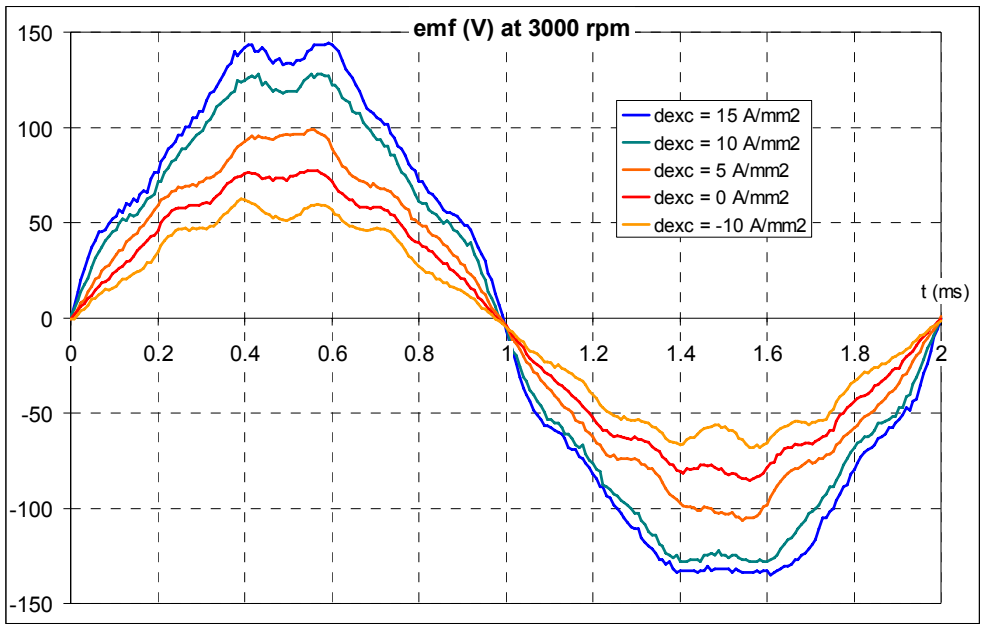

Fig. 6. Measured no-load voltage at 3000 rpm

This amplitude modulation is useful under driving operation and also under generating operation associated a bridge of diode.

\subsection{Harmonics elimination}

In order to eliminate the harmonics components, the iron sheets of the rotor are mounted with a shift angular angle. The shift electrical angle is $7.2^{\circ}$ to eliminate the $5 \mathrm{n}$ harmonics components. 


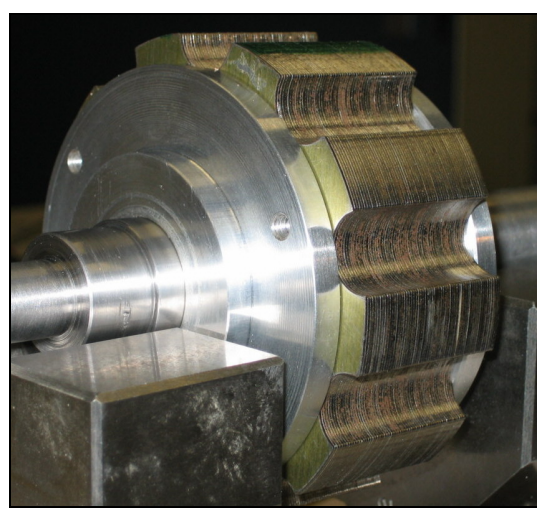

Fig. 7. Initial rotor

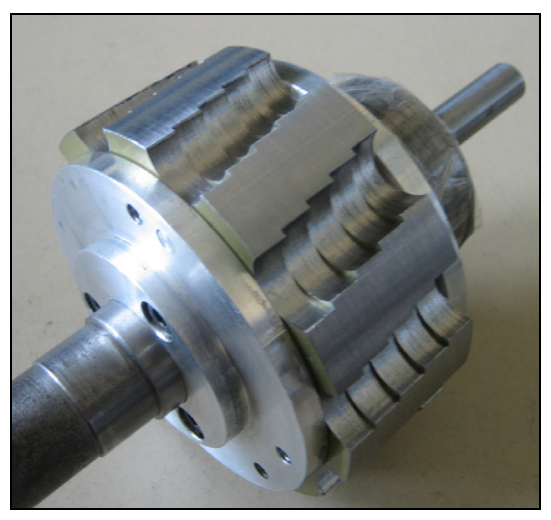

Fig. 8. Modified rotor

In the following figure, the no-load voltage with the modified rotor is clearly most sinusoidal.

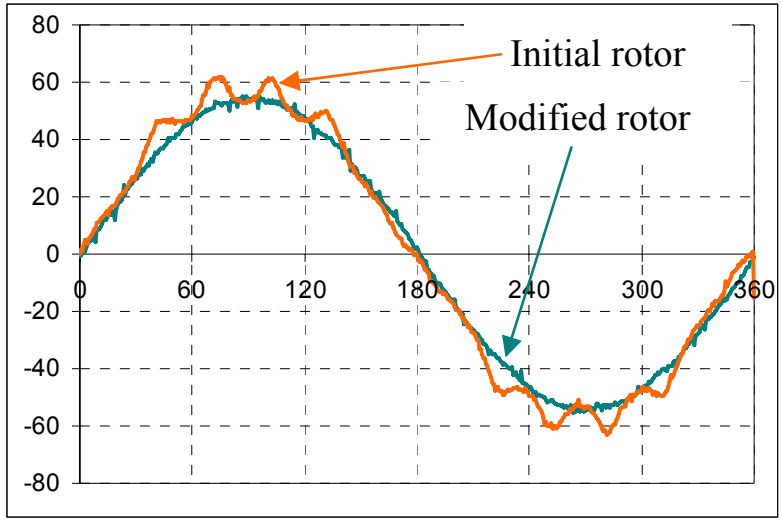

Fig. 9. No load voltage with two configurations of the rotor sheets

\section{Characteristics and performances}

\subsection{Experimental bench}

By virtue of its passive rotor, this machine displays highly robust qualities. Moreover, it is capable of attaining a good level of performance (continuous thermal specific torque). In association with a three phase voltage bridge converter, this machine can work with a constant maximum power over a theoretically infinite range of speeds in the flux weakening mode [5-7].

In fig. 10, we present the classical associated converter and we specify the experimental measurement.

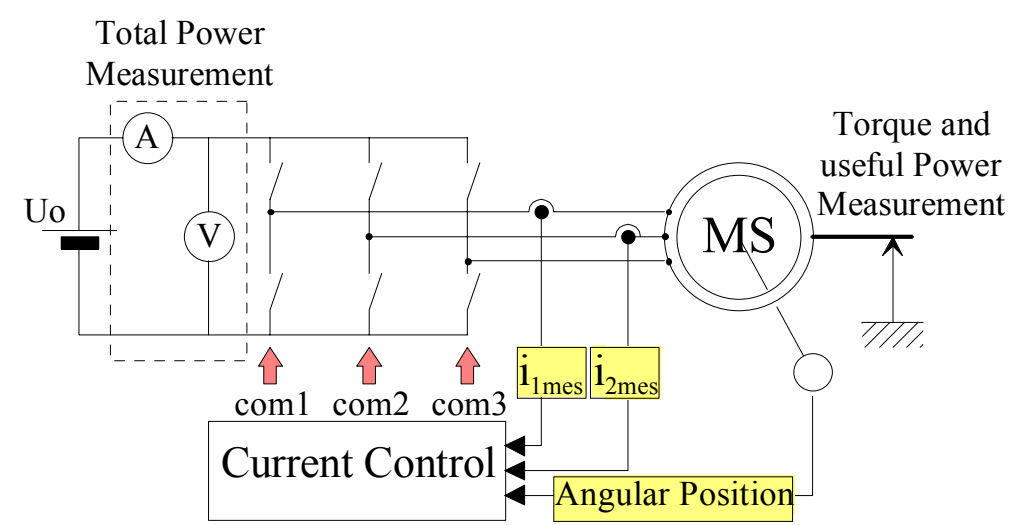

Fig. 10. Diagram of current regulated - machine drive

The hybrid excitation allows the modulation of the permanent magnets flux when energy needs are not maximal such as at "at no-load work". In this structure, the iron losses can be reduced with the flux weakening and with the wound excitation. It's necessary to use a DC-DC converter to create the current 
for the wound excitation. The power of this converter is about $200 \mathrm{~W}$ when the converter power with the machine associated with three phase voltage bridge converter is about $3 \mathrm{~kW}$.

In fig. 11 , we present the assembly experimental test. An induction machine, MAS (3000 rpm - 5 $\mathrm{kW})$, supply with an inverter can be used in motor mode or in generator mode. The DC bus $(300 \mathrm{~V})$ is the same for the two converter. The total power $\left(\mathrm{U}_{\mathrm{DC}} \times \mathrm{I}_{0 \mathrm{~T}}\right)$ is equal to the sum of the losses. With the contactors $\mathrm{K}_{\mathrm{MS}}$ and $\mathrm{K}_{\mathrm{MAS}}$ and with the coupling A, we can have different solutions to test the prototype, MS.

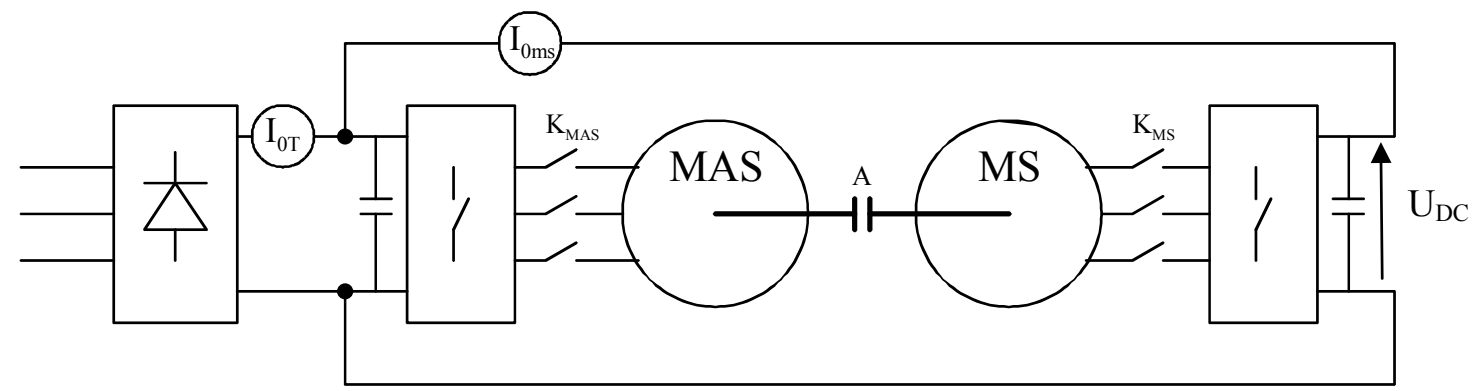

Fig. 11. Experimental bench

\subsection{Torque}

To measure the torque, we feed the machine with sinusoidal currents, and we use a mechanical assembly balances. The current density can vary up to $63 \mathrm{~A} / \mathrm{mm}^{2}$ (electronic limit). The thermal torque (permanent working) is obtained with a rated value of $10 \mathrm{~A} / \mathrm{mm}^{2}$ and with a current density of the wound excitation of $13 \mathrm{~A} / \mathrm{mm}^{2}$.

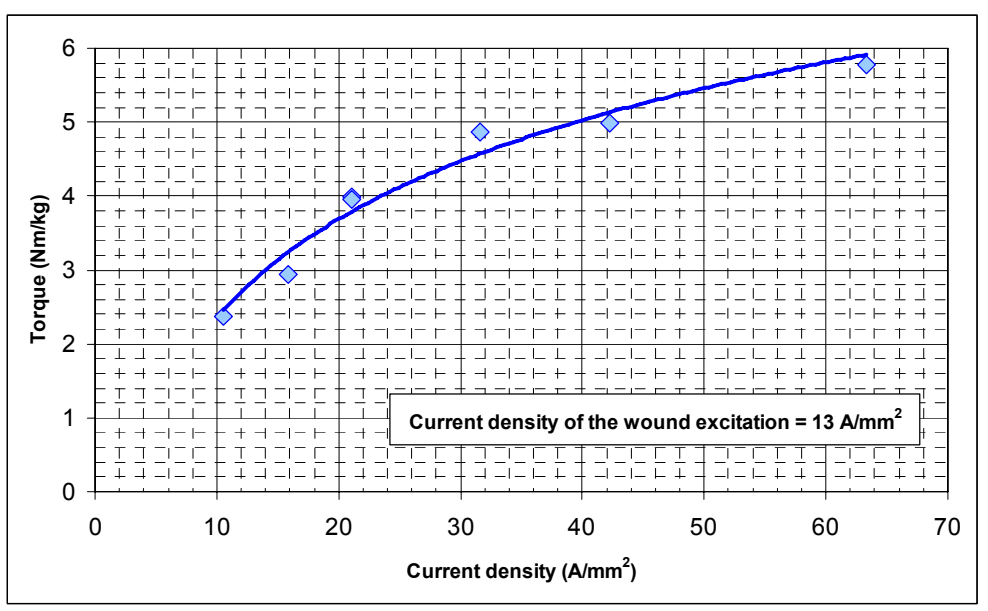

Fig. 12. Experimental torque versus armature current density

We can see on fig. 12, which the permanent massive torque is about $2.2 \mathrm{Nm} / \mathrm{kg}$ and for transient working is can reach about $6 \mathrm{Nm} / \mathrm{kg}$.

\subsection{Iron losses}

We have measured the iron losses in alternator mode at no-load ( $\mathrm{K}_{\mathrm{MAS}}$ closed, A closed, $\mathrm{K}_{\mathrm{MS}}$ open). In Fig. 13, we can see that the modulated excitation can reduce iron losses. 


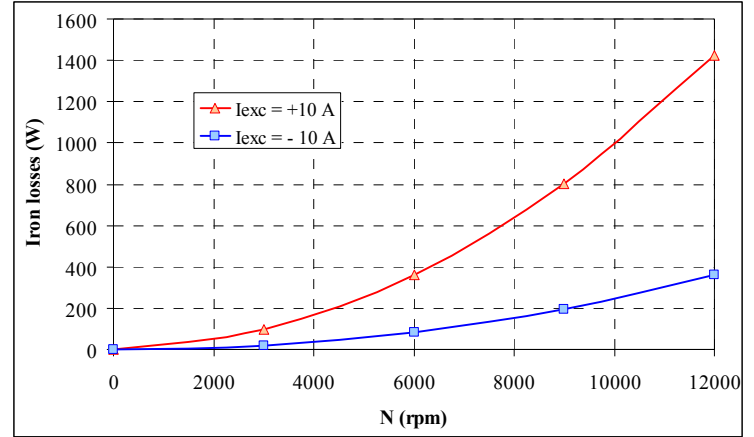

Fig. 13. Iron losses in alternator at no-load

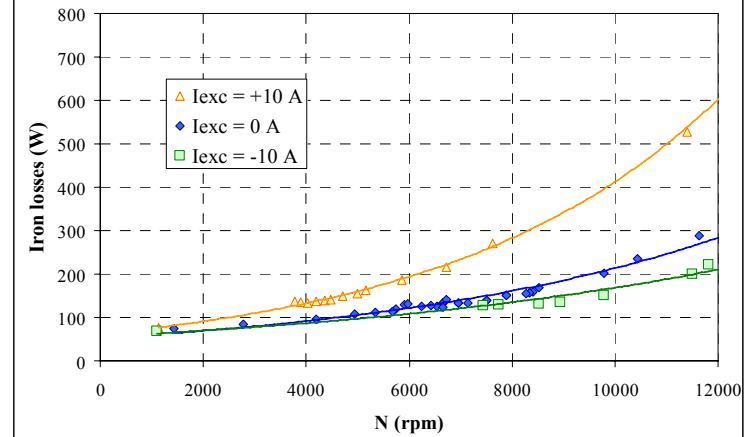

Fig. 14. Iron losses in motor mode at no-load

When the machine is associated with a three phase voltage bridge converter, we have measured iron losses in a motor mode at no-load ( $\mathrm{K}_{\mathrm{MAS}}$ open, $\mathrm{A}$ open, $\mathrm{K}_{\mathrm{MS}}$ closed). In Fig. 14, we can see that the flux weakening and the modulated excitation can reduce iron losses.

\subsection{Power capability}

In this section, our main focus lies in the energy-conversion possibilities of the machine when associated with a regulated current power converter. In particular, we have examined the machine's power capabilities with respect the limited voltage of the DC source or the breakdown voltage of the transistors, as well as the machine's constraints (global machine heat, i.e. efficient current limitation at lower speeds) and we fixed the excitation current at its rated value. In order to convert the maximum of power, we adjust the current in the direct axis (flux weakening mode).

On fig. 15 :

$\mathrm{P}_{\mathrm{abs}}$ : Total absorbed power $\left(\mathrm{U}_{\mathrm{DC}} \times \mathrm{I}_{0 \mathrm{MS}}\right)$ by the prototype associated with the converter.

$\mathrm{P}_{\mathrm{u}}$ : Useful output power measured with the balanced torque and the revolution speed.

$\mathrm{P}_{\mathrm{J}_{-} \text {ind }}$ : Copper losses in the armatures phases.

$\mathrm{P}_{\text {_ond }}$ : Estimated losses in the converter.

$\mathrm{P}_{\text {fer }}$ : Iron losses estimated with the separated losses method.

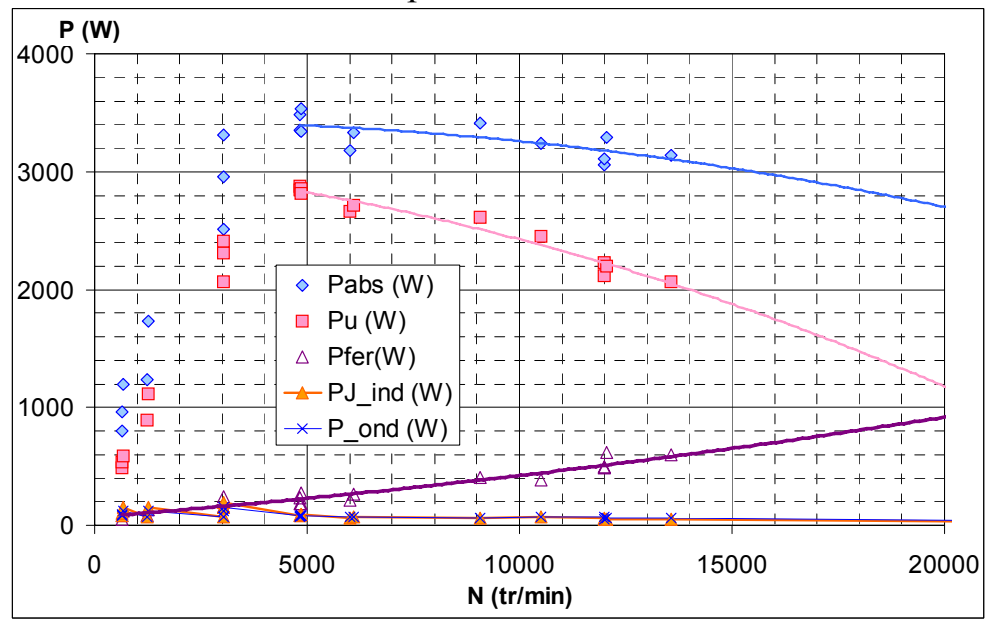

Fig. 15. Experimental assessment of the power for $I_{\mathrm{exc}}=10 \mathrm{~A}$

Although normalised inductance in the direct axe is higher than the unit, which means that we can convert a constant power on a theoretically infinite speed range, we note that the maximum power is not constant.

We can justify this fact with the electromagnetic model including the iron losses of the figure 16 [9].

In this model, $r$ represents the resistance of the phase, $L$ the cyclic inductance, $R_{f}$ the iron losses equivalent resistor and $\mathrm{E}$ the electromagnetic force. 
$\mathrm{k}$ is a coefficient which makes it possible to dissociate the sinusoidal magnetic flux crossing the airgap and the flux, or rather the density of flux in the magnetic circuit.

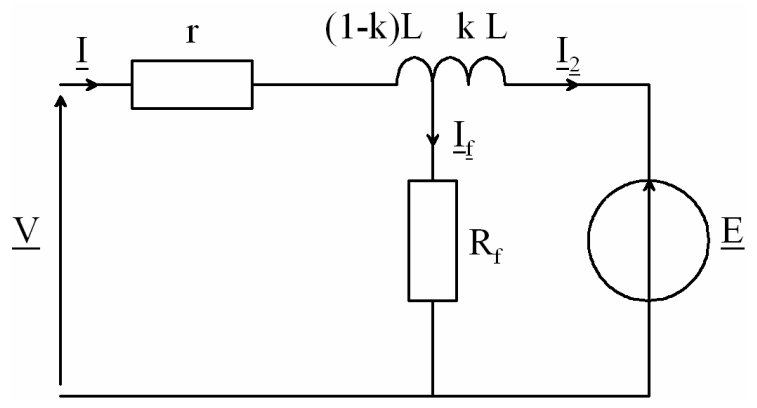

Fig. 16. Electromagnetic model with iron losses

We calculated the convertible maximum power with a coefficient $\mathrm{k}$ equal to 0.5 . This value can be given in an experimental way by determining the losses iron in generating mode in open circuit or short-circuit.

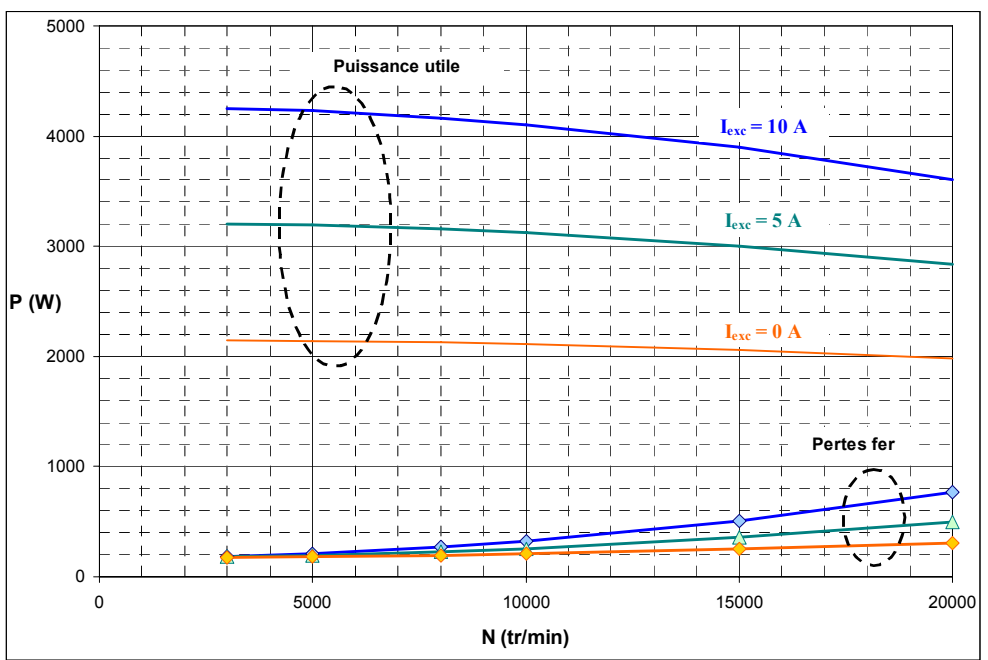

Fig. 17. Influence of the excitation current on converted power and on iron losses

On figure 17, we calculated the convertible maximum power ("puissance utile") for three fixed values of the excitation current (10 A, $5 \mathrm{~A}$ and $0 \mathrm{~A}$ ). In order to convert the maximum of power, we use the machine in flux weakening mode (we adjust the current in the direct axis). We can note that the part of the adjustable excitation makes it possible to decrease the iron losses ("pertes fer'") when one wish to convert a power lower than the maximum power.

\section{Applications}

We think that this new structure can be employed to make a high speed motor, or motor for difficult thermal environment, or more a high torque / low speed machine with higher pole number to make, for example, a low speed gearless wind generator [8]. This machine seems very interesting for applications requiring a strong transient mass couple and not very important losses to high revolution speed, for example for hybrid car.

\section{Conclusion}

This paper presents a new structure for a hybrid excitation; a synchronous polyphased machine based on the switching flux principle with a concentrated flux, and with permanent magnets excitation and wound excitation. The armature and inductor are both located inside the stator. The intrinsic performance obtained is most encouraging. 
We began by presenting the elementary cell and the switching flux principle. Then we introduce a hybrid synchronous three phase machine, along with its intrinsic characteristics.

We presented an advantage of this structure that is the possibility to modulate the excitation flux and its consequence on iron losses.

\section{Appendix}

\begin{tabular}{|l|l|}
\hline \multicolumn{1}{|c|}{ Mechanical characteristics } & \multicolumn{1}{c|}{ Electrical characteristics } \\
\hline External diameter $: 130 \mathrm{~mm}$ & Flux linkage (rated excitation) $: 42 \mathrm{mWb}$ \\
\hline Inner diameter $: 80 \mathrm{~mm}$ & Rated current $: 8.5 \mathrm{~A}$ \\
\hline Airgap length $: 0.2 \mathrm{~mm}$ & Rated excitation current $: 10 \mathrm{~A}$ \\
\hline Active length $: 30 \mathrm{~mm}$ & Inductance $: 5 \mathrm{mH}$ \\
\hline Stator iron mass $: 1.05 \mathrm{~kg}$ & Phase resistance $: 0.5 \Omega$ \\
\hline Rotor iron mass $: 0.86 \mathrm{~kg}$ & Excitation resistance $: 1.3 \Omega$ \\
\hline Permanent magnet $: \mathrm{N}_{\mathrm{e}} \mathrm{F}_{\mathrm{e}} \mathrm{B}-\mathrm{B}_{\mathrm{r}}=1.2 \mathrm{~T}$ & \\
\hline Permanent magnet volume $: 18 \mathrm{~cm}^{3}-0.135 \mathrm{~kg}$ & \\
\hline Phases copper mass $: 0.29 \mathrm{~kg}$ & \\
\hline Excitation copper mass $: 0.33 \mathrm{~kg}$ & \\
\hline
\end{tabular}

\section{References}

[1] E. HoANG, M. LECRIVAIN, M. GABSI

Machine électrique à commutation de flux et à double excitation

Brevet $\mathrm{n}^{\circ}$ de dépôt FR0602058, déposant : CNRS, 8 mars 2006.

[2] E. HoANG, A.H. BEN AHMED, J. LuCIDARME

Switching Flux Permanent Magnet Polyphased Synchronous Machines

EPE-97 Conf., Trondheim, September 1997.

[3] E. HoAng, M. Gabsi, M. Lecrivain, B. Multon

Influence of Magnetic Losses on Maximum Power Limits of Synchronous Permanent Magnet Drives in FluxWeakening Mode.

IAS'2000, Roma, Italy, 8-12 Oct. 2000.

[4] Z. Q. Zhu, Y. PANG, D. Howe, S. Iwasaki, R. DeOdhar and A. Pride

Analysis of Electromagnetic Performance of Flux-Switching Permanent-Magnet Machines by Nonlinear Adaptive Lumped Parameter Magnetic Circuit Model

IEEE Transactions on magnetics, vol. 41, $\mathrm{n}^{\circ}$ 11, Nov. 2005

[5] W.L. SOONG, Prof. T.J.E. MILLER

Field-weakening performance of brushless synchronous AC motor drives

IEE Proc.-Elect. Power Appl., Vol. 141, n 6, pp. 331-340, November 1994.

[6] T.M. JAHNS

Flux-weakening regime operation of an interior permanent-magnet synchronous motor drive

IEEE Trans. on Industry Applications, Vol. IA-231, n 4, pp. 681-689, July/August 1995.

[7] R.F. SCHIFERL, T.A. LIPO

Power capability of salient pole permanent magnet synchronous motors in variable speed drive applications IEEE Trans. on Industry Applications, Vol. 26, n 1, pp. 115-122, January/February 1995.

[8] A. BINDER, T. SCHNEIDER

Permanent magnet synchronous generators for regenerative energy conversion - a survey

EPE 2005, Dresden, Germany.

[9] O. AGLÉN

Loss calculation and thermal analysis of a high-speed generator

Electric Machines and Drives Conference, 2003. IEMDC'03 